\title{
Article
}

\section{The Effect of Heat Flux to the Fire-Technical and Chemical Properties of Spruce Wood (Picea abies L.)}

\author{
Martin Zachar ${ }^{1}$, Iveta Čabalová ${ }^{2, *} \mathbb{D}$, Danica Kačíková ${ }^{1}$ and Lucia Zacharová ${ }^{3}$ \\ 1 Department of Fire Protection, Faculty of Wood Sciences and Technology, Technical University in Zvolen, \\ 96001 Zvolen, Slovakia; zachar@tuzvo.sk (M.Z.); kacikova@tuzvo.sk (D.K.) \\ 2 Department of Chemistry and Chemical Technologies, Faculty of Wood Sciences and Technology, \\ Technical University in Zvolen, 96001 Zvolen, Slovakia \\ 3 National Forest Centre, Forest Research Institute, 96001 Zvolen, Slovakia; lucia.ambrusova@nlcsk.org \\ * Correspondence: cabalova@tuzvo.sk; Tel.: +421-455206375
}

check for updates

Citation: Zachar, M.; Čabalová, I.;

Kačíková, D.; Zacharová, L. The Effect of Heat Flux to the Fire-Technical and Chemical Properties of Spruce Wood (Picea abies L.). Materials 2021, 14, 4989. https://doi.org/10.3390/ma14174989

Academic Editors: Michael Försth and Oisik Das

Received: 9 August 2021

Accepted: 30 August 2021

Published: 31 August 2021

Publisher's Note: MDPI stays neutral with regard to jurisdictional claims in published maps and institutional affiliations.

Copyright: (c) 2021 by the authors. Licensee MDPI, Basel, Switzerland. This article is an open access article distributed under the terms and conditions of the Creative Commons Attribution (CC BY) license (https:// creativecommons.org/licenses/by/ $4.0 /)$.

\begin{abstract}
The paper assesses the influence of the heat flux on spruce wood (Picea abies L.) behavior. The heat flux was performed at $15,20,25$, and $30 \mathrm{~kW} \cdot \mathrm{m}^{-2}$. The fire-technical properties, such as the mass burning rate, charring thickness, charring rate, as well as the chemical composition (contents of the extractives, lignin, cellulose, holocellulose), of wood were determined. The highest burning rate of spruce wood of $0.32 \% \cdot \mathrm{s}^{-1}$ was reached at the heat flux of $30 \mathrm{~kW} \cdot \mathrm{m}^{-2}$. The charring rate ranged from $1.004 \mathrm{~mm} \cdot \mathrm{min}^{-1}\left(15 \mathrm{~kW} \cdot \mathrm{m}^{-2}\right)$ to $2.016 \mathrm{~mm} \cdot \mathrm{min}^{-1}\left(30 \mathrm{~kW} \cdot \mathrm{m}^{-2}\right)$. The proposed model of the charring process of spruce wood in time and appropriate thickness as a selected parameter is applicable in validation of the results of computer fire models in the design of fire protection of wooden buildings. The decrease in the holocellulose content mostly caused by the degradation of hemicelluloses was observed during thermal loading. The biggest decrease in hemicelluloses $(24.94 \%)$ was recorded in samples loaded at $30 \mathrm{~kW} \cdot \mathrm{m}^{-2}$. The contents of cellulose increased due to the structural changes (carbonization and crosslinking), the content of lignin increased as well due to its higher thermal stability compared to saccharides, as well as the resulting lignin condensation.
\end{abstract}

Keywords: spruce wood; heat flux; charring thickness; charring rate; chemical composition

\section{Introduction}

Wood and wood composites represent a main part of the fuel in many building fires [1] The ability of materials to ignite when heated at elevated temperatures depends on many factors, such as the thermal properties [2-4], the chemical composition of materials [5-7], the ignition temperature [8-10], the heat flux, and the environment [1,11]. Under fire exposure, wood is degraded with heat transfer and weight loss [12,13]. During the combustion, the processes such as pyrolysis, ignition, radiation, and char formation occur in wood $[14,15]$.

Charring rate is one of the most important fire properties of wood and wood products. It is one of the input data for calculation of fire resistance of wooden constructions according to STN EN 1995-1-2 (Eurocode 5) [16]. To enhance both the compression stability and fire resistance of wood, Chu et al. [17] used a new modification method; combined nitrogenphosphorus (NP) fire retardant pre-impregnated with surface thermo-mechanical densification.

In addition, the charring rate of wood is a significant parameter in the determination of the fire cause, which is in line with NFPA 921: 2021 [18]. Technical standard (Eurocode 5) is the most reliable for charring depth analysis in assessment of the fire spread. To determine the burning time and the intensity of the fire, it defines the charring depth as a distance between the outer side of the surface of the original element and the position of the line between the charred layer and the rest of the cross-section. The standard considers the line of the charred layer of the wooden constructions as a place where the temperature reaches $300{ }^{\circ} \mathrm{C}$. The charring rate of wood depends on the density, moisture content, heat flux, 
and oxygen concentration of the environment [19]. Fonseca and Barreira [20] measured the charred layer in five different places using thermocouples " $\mathrm{K}$ " and MGC Plus data acquisition system. The temperature was measured at different depths, i.e., 10, 20, 30, and $40 \mathrm{~mm}$ under the surface exposed to heat, and they found that the interface between thermal degraded and non-degraded wood is the border between the black and brown layer of the wood and is characterized by a temperature of $300{ }^{\circ} \mathrm{C}$. According to White and Nordheim [21], the charred layer corresponds to a temperature of $288^{\circ} \mathrm{C}$. The results of the scientific papers by Findorák et al. [22] and Chen et al. [23] confirm that the rapid thermal decomposition of wood (in case of short-term exposure) begins at a temperature just below $300{ }^{\circ} \mathrm{C}$. According to Babrauskas [24], the chairing rate has been the subject of interest of building safety experts, who wanted to determine the decrease in load-bearing capacity of wooden beams and columns in post-flashover. Standard test equipment to simulate flashover (test furnaces) was used to obtain these data. The test conditions were determined in line with ASTM E119-20 [25] or ISO 834-2 [26]. During his tests, the furnace was heated to a constant temperature. Spruce samples were put into the furnace and were exposed to the radiant environment of the furnace where the temperature ranged from 920 to $1070{ }^{\circ} \mathrm{C}$.

Heating may cause changes in the main chemical components (cellulose, hemicelluloses, and lignin) and extractives of wood and their contents [6,27]. During thermal loading, hemicelluloses degrade first, resulting in the formation of various volatile compounds [28]. High temperatures cause also the degradation of lignin, resulting in the production of water, carbon dioxide, formic acid, acetic acid, and other substances that can be involved in condensation reactions [29]. Thermal degradation of the hemicelluloses starts at lower temperatures compared to lignin and cellulose [30]. According to the papers of Rantuch and Chrebet [31]; Gaan et al. [32], three steps of thermal decomposition of cellulose are indicated: the first stage at around $100{ }^{\circ} \mathrm{C}$, which corresponds to the release of physically absorbed water; the second stage at around $360^{\circ} \mathrm{C}$ (very rapid), corresponding to the dehydration and decarboxylation with production of combustible gasses; and the third stage (slow) at around $400{ }^{\circ} \mathrm{C}$, which corresponds to the decomposition of the carbon formed in the second stage. Polleto [33] studied two wood species, Pinus taeda and Eucalyptus grandis. According to his results obtained from the thermogravimetric analysis, the water loss was observed at around $100{ }^{\circ} \mathrm{C}$ for both wood species. The thermal degradation occurred as a two-step process; in the first, the degradation of hemicelluloses took place at around $300{ }^{\circ} \mathrm{C}$. The main degradation of cellulose occurs at around $350{ }^{\circ} \mathrm{C}$ for both species.

For an assessment of all the factors that influence the possibility of fire initiation, it is very important to know the fire-technical properties and the chemical composition of the wood. This paper deals with the influence of the heat flux $\left(15,20,25\right.$, and $\left.30 \mathrm{~kW} \cdot \mathrm{m}^{-2}\right)$ on spruce wood behavior. Spruce wood is the most common coniferous tree in Slovakia and is very often used in construction. From the fire-technical properties, the mass burning and charring rate and chemical composition (lignin, cellulose, hemicelluloses and extractives) of spruce wood were evaluated. Based on the determined temperatures at individual depths of samples and using statistical methods of least squares, a model of the course of charring in the given time and depth was created.

Fire-technical properties, such as the mass burning rate, charring rate, and chemical composition (lignin, cellulose, hemicelluloses and extractives), of spruce wood were evaluated. Based on the determined temperatures at individual depths of 10, 20, 30, and $40 \mathrm{~mm}$ under the surface of test samples loaded with a ceramic infrared heater with a heat flux of $15,20,25$, and $30 \mathrm{~kW} \cdot \mathrm{m}^{-2}$ and using statistical methods of least squares, a model of the course of charring in the given time and depth was created. This method has not been published in any original scientific paper yet. The paper will be useful to determine the fire investigation. 


\section{Materials and Methods}

\subsection{Materials}

Samples for experimental work were made from spruce (Picea abies (L.) H. Karst.). A 120-year old tree was cut in location of Zvolen (altitude $800 \mathrm{~m}$ above sea level) in summer 2020. The dimension of the trunk was $420 \mathrm{~mm}$ and the moisture content was $41 \%$. Subsequently, the trunk was cut using a band saw to a thickness of $55 \mathrm{~mm}$ and dried in a dryer to $15 \%$ moisture content. Test samples with diameters of $40 \times 50 \times 50 \mathrm{~mm}$ (transverse $\times$ radial $\times$ tangential direction) were dried to $0 \%$ moisture content, which was maintained until testing. The density of test samples was $443.61 \pm 12 \mathrm{~kg} \cdot \mathrm{m}^{-3}$. Elementary analysis was conducted; its results are summarized in Table 1. Elementary analysis was carried out as follows: carbon (C) was determined according to STN ISO 10694 [34] using elementary analysis with thermally conductive analysis; nitrogen $(\mathrm{N})$ according to ISO 13878 [35], using elementary analysis with thermally conductive analysis; sulfur (S) according to ISO 15178 [36], using elementary analysis with thermally conductive analysis; phosphor $(\mathrm{P})$, calcium $(\mathrm{Ca})$, magnesium $(\mathrm{Mg})$, and potassium $(\mathrm{K})$ according to ISO 11885 [37], using atomic emission spectrometry with inductively coupled plasma.

Table 1. Elementary analysis of spruce wood used for the experiment.

\begin{tabular}{|c|c|c|c|c|c|c|c|}
\hline Element & $\begin{array}{c}\mathrm{C} \\
\left(\mathrm{g} \cdot \mathrm{kg}^{-2}\right)\end{array}$ & $\begin{array}{c}\mathrm{N} \\
\left(\mathrm{g} \cdot \mathrm{kg}^{-2}\right)\end{array}$ & $\begin{array}{c}\mathrm{S} \\
\left(\mathrm{mg} \cdot \mathrm{kg}^{-2}\right)\end{array}$ & $\begin{array}{c}P \\
\left(\mathrm{~g} \cdot \mathrm{kg}^{-2}\right)\end{array}$ & $\begin{array}{c}\mathrm{Ca} \\
\left(\mathrm{g} \cdot \mathrm{kg}^{-2}\right)\end{array}$ & $\begin{array}{c}\mathrm{Mg} \\
\left(\mathrm{g} \cdot \mathrm{kg}^{-2}\right)\end{array}$ & $\frac{\mathrm{K}}{\left(\mathrm{g} \cdot \mathrm{kg}^{-2}\right)}$ \\
\hline Spruce wood & 489 & 1.32 & 299 & 0.151 & 0.702 & 0.044 & 0.621 \\
\hline
\end{tabular}

\subsection{Methods}

During the experiment, proposed measurement apparatus, in line with the utility model application No. 50121-2020, registered by the Industrial Property Office of the Slovak Republic, was used. The apparatus consists of a ceramic infrared heater (type F.T.E. with power of $1000 \mathrm{~W}$, Ceramicx Ltd., Gortnagrough, Ireland), accurate digital scales (Radwag PS 3500.R2, RADWAG Balances and Scales, Radom, Poland), a control device (METREL HSN0203, Metrel d.d. Horjul, Slovenia), temperature measuring devices (Data logger ALMEMO ${ }^{\circledR} 710$, Ahlborn Mess- und Regelungstechnik GmbH, Holzkirchen, Germany), type " $K$ " thermocouples with a thickness of $0.5 \mathrm{~mm}$ (Omega Engineering Inc., Norwalk, CT, USA), and an initiation burner (propane burner CLASIC CZ, Ltd., Řevnice, Czech Republic).

\subsubsection{The Mass Burning Rate}

The reaction to fire tests were determined according to the EN ISO 11925-2 standard [38]. The mass burning rate was measured with apparatus described above. The sample was placed into the holder at a distance of $30 \mathrm{~mm}$ from the ceramic infrared heater, for a specific time of $1920 \mathrm{~s}$, and the weight change was recorded every $10 \mathrm{~s}$. The heat flux of the infrared heater was $15,20,25$, and $30 \mathrm{~kW} \cdot \mathrm{m}^{-2}$. For the purpose of thermal loading with ceramic infrared heater, the samples were divided into 10 series of 5 samples for each value of the heat flux.

To determine the burning rate in the specified time interval, the absolute burning rate $v$ was calculated according to Equation (1):

$$
\vartheta=(\delta(\tau)-\delta(\tau+\Delta \tau)) / \Delta \tau
$$

where:

- $\vartheta$-absolute burning rate $\left(\% \cdot \mathrm{s}^{-1}\right)$;

- $\delta(\tau)$-sample weight in time $(\tau)(\%)$;

- $\delta(\tau+\Delta \tau)$-sample weight in time $(\tau+\Delta \tau)(\%)$;

- $\Delta \tau$-time interval in which the weight values are recorded (s). 


\subsubsection{Determination of the Charring Rate of Samples}

To determine the course of temperatures in spruce samples, it was necessary to place thermocouples into them. Thermocouples were placed in test samples at a distance of 10 (T1), 20 (T2), 30 (T3), and 40 (T4) $\mathrm{mm}$ under the surface and were loaded with a heat flux of $15,20,25$, and $30 \mathrm{~kW} \cdot \mathrm{m}^{-2}$.

Based on the recorded course of temperatures in the samples, we could determine the course of degradation of spruce wood without the need to manually measure the charring thickness. As it is stated in NFPA 921:2017 [18], the charring rate of wood depends on the amount of wood and a large number of variables (characteristics of wood) and fire conditions. To determine the burning time and fire intensity, STN EN 19951-2 (Eurocode 5) [16] can be applied, stating that the line of charred layer of wooden constructions is considered as a place where the temperature reaches $300^{\circ} \mathrm{C}$. Reaching a temperature of $300^{\circ} \mathrm{C}$ in test samples (at depths of $10,20,30$, and $40 \mathrm{~mm}$ ) was also decisive for our measurements to determine the depth of charring.

\subsubsection{Chemical Composition of Wood}

Samples were disintegrated into sawdust, and fractions from $0.5 \mathrm{~mm}$ to $1.0 \mathrm{~mm}$ in size were used for the chemical analyses. According to ASTM D1107-21 [39], the extractives content was determined in a Soxhlet apparatus with a mixture of ethanol and toluene (2:1). The lignin content was determined according to Sluiter et al. [40], the cellulose according to the method by Seifert [41], and the holocellulose according to the method by Wise et al. [42]. Hemicelluloses were calculated as a difference between the holocellulose and cellulose content. Measurements were performed on four replicates per sample. The results were presented as oven-dry wood percentages.

\section{Results and Discussion}

\subsection{Burning Rate of Test Samples}

The results of mass burning rate are shown in Figure 1, where the maximum burning rate values, as well as time of reaching these maximum burning rate values, are referred to depending on the heat flux of $15,20,25$, and $30 \mathrm{~kW} \cdot \mathrm{m}^{-2}$.

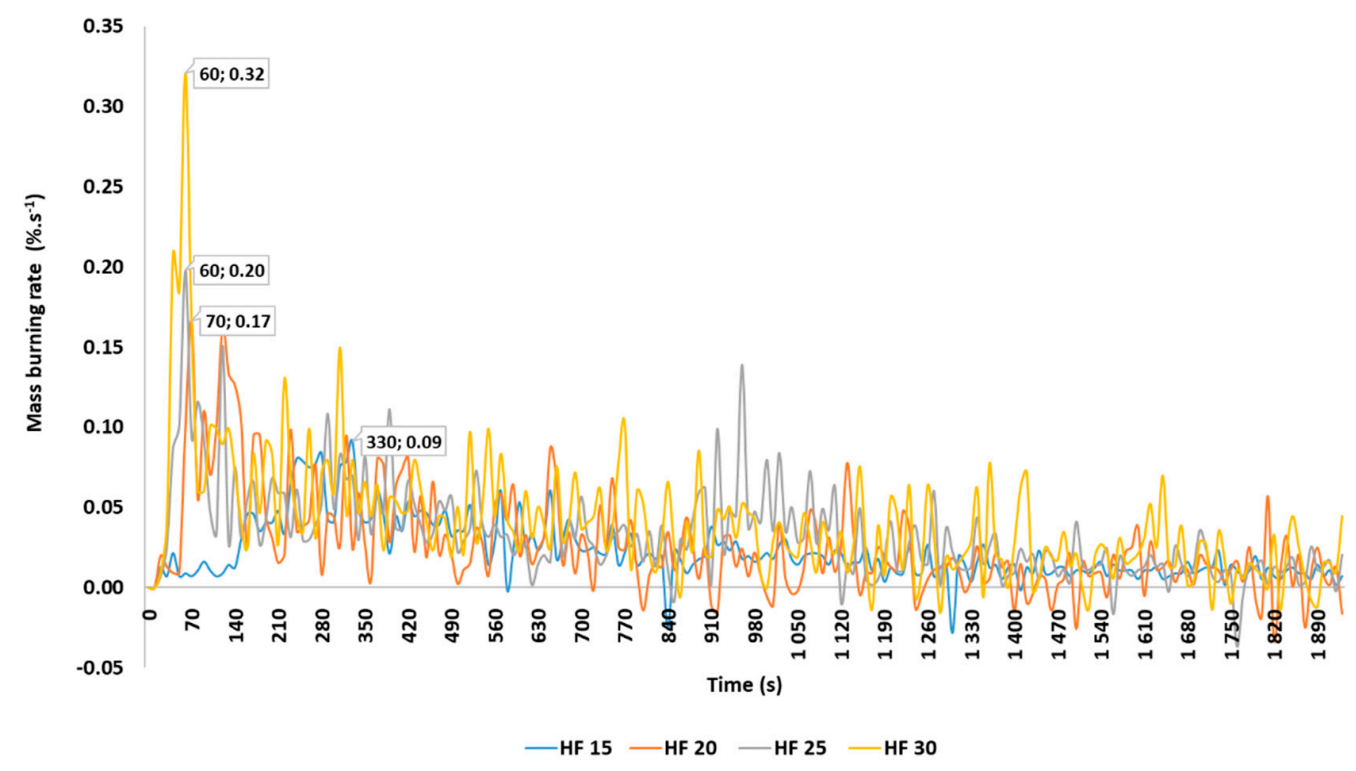

Figure 1. Absolute burning rate of the spruce wood samples.

Burning rate of spruce wood samples is calculated based on weight losses in time interval up to $1920 \mathrm{~s}$.

From the fire protection point of view, the time taken for the tested material to reach the given value of the flash point plays an important role. The results of our measurements 
show that, with increasing heat flux, the time to initiation of spruce samples decreases. At the thermal loading with a heat flux of $15 \mathrm{~kW} \cdot \mathrm{m}^{-2}$, the time to initiation was significantly higher $(261.5 \mathrm{~s})$, with a maximum burning rate of $0.09 \% \cdot \mathrm{s}^{-1}$. At the thermal loading with a heat flux of $20 \mathrm{~kW} \cdot \mathrm{m}^{-2}$, the time to initiation was $47.5 \mathrm{~s}$ and maximum burning rate was $0.17 \% \cdot \mathrm{s}^{-1}$. At the thermal loading with a heat flux of $25 \mathrm{~kW} \cdot \mathrm{m}^{-2}$, the time to initiation was $22.0 \mathrm{~s}$ and the maximum burning rate was $0.17 \% \cdot \mathrm{s}^{-1}$. At the thermal loading with a heat flux of $30 \mathrm{~kW} \cdot \mathrm{m}^{-2}$, the time to initiation was $11.25 \mathrm{~s}$ and the maximum burning rate was $0.32 \% \cdot \mathrm{s}^{-1}$. The time of reaching the maximum burning rate is changes significantly, depending on the heat flux. With increasing values of the heat flux, the interval for reaching the maximum burning rate of spruce samples decreases. According to the paper by Zachar et al. [43], in determining the time to initiation, in line with STN ISO 871 [44], for spruce wood samples prepared from root, branch, and trunk, we could observe a greater variability of the results. Values of ignition times ranged from $420 \mathrm{~s}$ for branch, $485 \mathrm{~s}$ for root, and up to $560 \mathrm{~s}$ for trunk. Delichatsios et al. [45], in testing spruce wood, reached an ignition temperature of approximately $478^{\circ} \mathrm{C}$ and an initiation time of $266 \mathrm{~s}$, which is comparable to our results. Hagen et al. [46], in testing spruce samples, reached an ignition temperature of approximately $488{ }^{\circ} \mathrm{C}$ and an initiation time of $253 \mathrm{~s}$. MakovickáOsvaldová et al. [47] assessed the initiation time of different tree species with dimensions of $9 \times 9 \times 1 \mathrm{~cm}$, loaded with a heat flux of $35 \mathrm{~kW} \cdot \mathrm{m}^{-2}$, using conical calorimeter. In the case of spruce wood, they stated that the initiation time ranges from 30 to $54 \mathrm{~s}$, which is comparable to our results. The burning rate was also measured by Gaff et al. [48], who reached a comparable burning rate of untreated teak wood of $0.18 \% \cdot \mathrm{s}^{-1}$ in an initiation time of $174 \mathrm{~s}$; in the case of thermally treated samples, values of the maximum burning rate were higher, ranging from 0.23 to $0.33 \% \cdot \mathrm{s}^{-1}$. Kačíková and Makovická [49] compared the burning rate of coniferous species, finding that the lowest rate of $0.09 \% \cdot \mathrm{s}^{-1}$ was reached for spruce wood. Makovická-Osvaldová et al. [50] determined the burning rate of spruce wood loaded with propane burner in a time interval from 0.08 to $0.095 \% \cdot \mathrm{s}^{-1}$, which is comparable to our results.

\subsection{Charring Rate of Test Samples}

The charring rate was determined based on time measurement until a temperature of $300{ }^{\circ} \mathrm{C}$ was reached (Table 2$)$.

Table 2. Thickness and charring rate of test samples. The values are the mean \pm the SD.

\begin{tabular}{|c|c|c|c|}
\hline $\begin{array}{l}\text { Heat Flux } \\
\left(\mathbf{k W} \cdot \mathrm{m}^{-2}\right)\end{array}$ & $\begin{array}{l}\text { Time of Thermal Loading } \\
\text { (s) }\end{array}$ & $\begin{array}{l}\text { Charring Thickness } \\
\text { (mm) }\end{array}$ & $\begin{array}{l}\text { Charring Rate } \\
\left(\mathrm{mm} \cdot \mathrm{min}^{-1}\right)\end{array}$ \\
\hline 15 & $505 \pm 5.50$ & $10 \pm 0.15$ & 1.188 \\
\hline 15 & $1195 \pm 6.20$ & $20 \pm 0.05$ & 1.004 \\
\hline 15 & - & - & - \\
\hline 20 & $391 \pm 1.40$ & $10 \pm 0.13$ & 1.535 \\
\hline 20 & $811 \pm 4.80$ & $20 \pm 0.72$ & 1.479 \\
\hline 20 & - & - & - \\
\hline 25 & $298 \pm 3.10$ & $10 \pm 0.18$ & 2.013 \\
\hline 25 & $726 \pm 6.60$ & $20 \pm 0.25$ & 1.653 \\
\hline 25 & $1364 \pm 7.10$ & $30 \pm 0.51$ & 1.424 \\
\hline 30 & $314 \pm 2.50$ & $10 \pm 0.09$ & 1.911 \\
\hline 30 & $596 \pm 3.30$ & $20 \pm 0.35$ & 2.016 \\
\hline 30 & $977 \pm 5.00$ & $30 \pm 0.46$ & 1.842 \\
\hline
\end{tabular}

An average temperature of $300{ }^{\circ} \mathrm{C}$ reached on individual thermocouples $\mathrm{T} 1, \mathrm{~T} 2$, and T3 loaded with a heat flux of $15,20,25$, and $30 \mathrm{~kW} \cdot \mathrm{m}^{-2}$ corresponds to the respective charring depth and, subsequently, to charring rate. The lowest charring rates were reached under a thermal load of $15 \mathrm{~kW} \cdot \mathrm{m}^{-2}$, i.e., $1.188 \mathrm{~mm} \cdot \mathrm{min}^{-1}$ in a time of $505 \mathrm{~s}$ (T1) and $1.004 \mathrm{~mm} \cdot \mathrm{min}^{-1}$ (T2) in a time of $1195 \mathrm{~s}$. On other thermocouples (T3 and T4) at a thermal loading of $15 \mathrm{~kW} \cdot \mathrm{m}^{-2}$, a temperature of $300{ }^{\circ} \mathrm{C}$ was not reached within $1920 \mathrm{~s}$ (end of 
thermal loading of samples); therefore, it was not possible to determine the charring depth and rate. At a thermal loading of $20 \mathrm{~kW} \cdot \mathrm{m}^{-2}$, a temperature of $300^{\circ} \mathrm{C}$ was reached in a time of $391 \mathrm{~s}$ (T1), and the charring rate was $1.535 \mathrm{~mm} \cdot \mathrm{min}^{-1}$; on thermocouple $\mathrm{T} 2$, in a time of $811 \mathrm{~s}$, the charring rate was $1.479 \mathrm{~mm} \cdot \mathrm{min}^{-1}$. On other thermocouples (T3 and T4), at a thermal loading of $20 \mathrm{~kW} \cdot \mathrm{m}^{-2}$, a temperature of $300{ }^{\circ} \mathrm{C}$ was not reached within $1920 \mathrm{~s}$. At a thermal loading of $25 \mathrm{~kW} \cdot \mathrm{m}^{-2}$, a temperature of $300^{\circ} \mathrm{C}$ was reached in a time of $298 \mathrm{~s}$ (T1), and the charring rate was $2.013 \mathrm{~mm} \cdot \mathrm{min}^{-1}$; on thermocouple $\mathrm{T} 2$, the charring rate was $1.653 \mathrm{~mm} \cdot \mathrm{min}^{-1}$, and on thermocouple $\mathrm{T} 3$, it was $1.424 \mathrm{~mm} \cdot \mathrm{min}^{-1}$, which indicates that the charring rate decreased towards the center of the sample. On thermocouple T4, at a thermal loading of $25 \mathrm{~kW} \cdot \mathrm{m}^{-2}$, a temperature of $300{ }^{\circ} \mathrm{C}$ was not reached within $1920 \mathrm{~s}$. At the highest thermal loading of $30 \mathrm{~kW} \cdot \mathrm{m}^{-2}$, a temperature of $300{ }^{\circ} \mathrm{C}$ was reached in a time of $314 \mathrm{~s}$ (T1), and the charring rate was $2.911 \mathrm{~mm} \cdot \mathrm{min}^{-1}$; on thermocouple $\mathrm{T} 2$, the charring rate of $2.016 \mathrm{~mm} \cdot \mathrm{min}^{-1}$ was reached in a time of $596 \mathrm{~s}$; on thermocouple T3, the charring rate of $1.842 \mathrm{~mm} \cdot \mathrm{min}^{-1}$ was reached in a time of $977 \mathrm{~s}$ (which are the shortest times of charring). On thermocouple $\mathrm{T} 4$, at a thermal loading of $30 \mathrm{~kW} \cdot \mathrm{m}^{-2}$, a temperature of $300{ }^{\circ} \mathrm{C}$ was not reached within $1920 \mathrm{~s}$; therefore, it was not possible to determine the charring depth and rate.

According to NFPA 921: 2017 [18], the charring rate of wood under laboratory conditions and exposure to a heat source from one side is determined from $0.17 \mathrm{~mm} \cdot \mathrm{min}^{-1}$ to $4.23 \mathrm{~mm} \cdot \mathrm{min}^{-1}$. Lipinskas and Mačiulaitis [51] investigated the charring of fir samples treated with various kinds of retardant using different test equipment. Using a heating chamber, they determined the charring rate of selected coniferous tree species, ranging from 0.6 to $1.1 \mathrm{~mm} \cdot \mathrm{min}^{-1}$.

The relationship between average charring rate of spruce wood and the heat flux density (in time intervals from 0 to $600 \mathrm{~s}$; from 0 to $900 \mathrm{~s}$; and from 0 to $1920 \mathrm{~s}$ ) is shown in Figure 2.

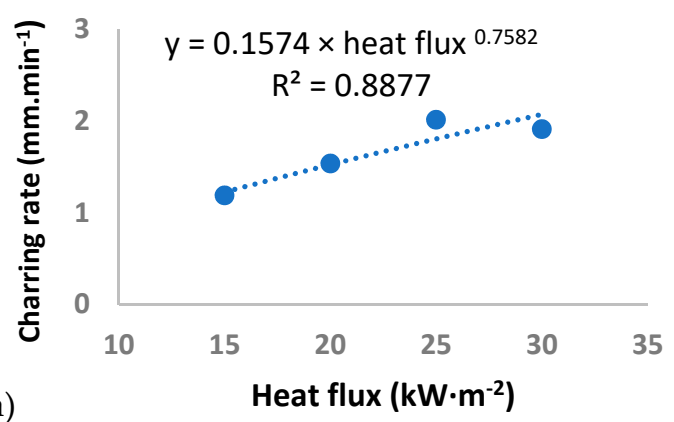

(a)

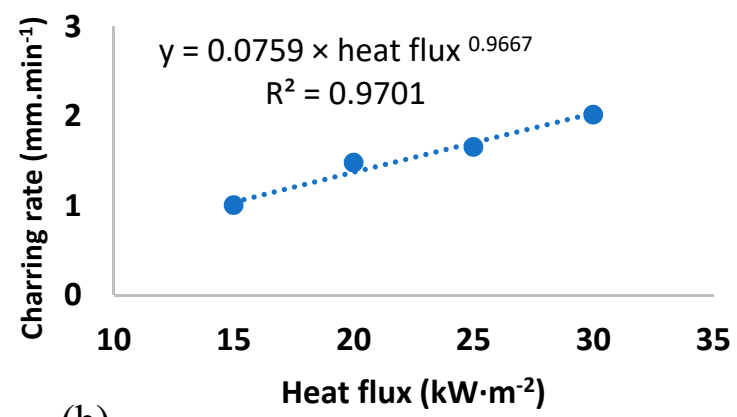

(b)

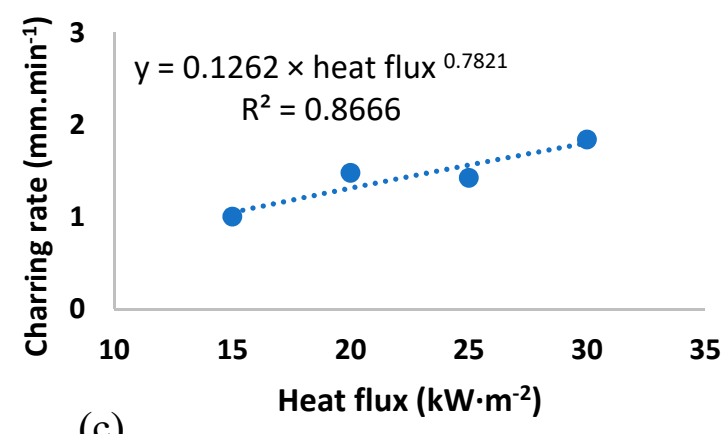

(c)

Figure 2. Average charring rate in time interval: (a) from 0 to $600 \mathrm{~s}$; (b) from 0 to $900 \mathrm{~s}$; (c) from 0 to $1920 \mathrm{~s}$.

The results show that the charring rate increases with increasing heat flux. In the time interval from 0 to $600 \mathrm{~s}$, the average charring rate ranged from $1.18 \mathrm{~mm} \cdot \mathrm{min}^{-1}$ (at a heat flux of $15 \mathrm{~kW} \cdot \mathrm{m}^{-2}$ ) to $2.01 \mathrm{~mm} \cdot \mathrm{min}^{-1}$ (at a heat flux of $30 \mathrm{~kW} \cdot \mathrm{m}^{-2}$ ). In the time interval from 0 to $900 \mathrm{~s}$, the average charring rate ranged from $1.00 \mathrm{~mm} \cdot \mathrm{min}^{-1}$ (at a heat flux of $15 \mathrm{~kW} \cdot \mathrm{m}^{-2}$ ) to $2.02 \mathrm{~mm} \cdot \mathrm{min}^{-1}$ (at a heat flux of $30 \mathrm{~kW} \cdot \mathrm{m}^{-2}$ ). In the time interval 
from 0 to $1920 \mathrm{~s}$, the average charring rate ranged from $1.00 \mathrm{~mm} \cdot \mathrm{min}^{-1}$ (at a heat flux of $15 \mathrm{~kW} \cdot \mathrm{m}^{-2}$ ) to $1.84 \mathrm{~mm} \cdot \mathrm{min}^{-1}$ (at a heat flux of $30 \mathrm{~kW} \cdot \mathrm{m}^{-2}$ ). Martinka et al. [52] described a significant linear relationship between the charring depth and the ratio of mass loss to density. The average charring rate decreases with increasing time, and increases with increasing heat flux. He stated that the average charring rate of spruce wood ranged from $0.73 \mathrm{~mm} \cdot \mathrm{min}^{-1}$ (at a heat flux of $20 \mathrm{~kW} \cdot \mathrm{m}^{-2}$ ) to $1.2 \mathrm{~mm} \cdot \mathrm{min}^{-1}$ (at a heat flux of $50 \mathrm{~kW} \cdot \mathrm{m}^{-2}$ ). The reason for the decreasing charring rate is mainly that the charred layer formed on the surface of the sample reduces the overheating and thermal decomposition of non-degraded wood under the charred layer. Similar results were also reached by other authors, e.g., Zhang [53] and Lizhong et al. [54], who tested various tree species at a heat flux of $15,25,35$, and $50 \mathrm{~kW} \cdot \mathrm{m}^{-2}$. Their conclusions show that the charring rate of wood exposed to a constant external heat flux can be considered as a linear function of time, but at a higher levels of heat flux, its behavior can be nonlinear, with longer intervals needed to reach a given charring depth. The rate of charring is directly proportional to the ratio of exposure to external heat flux and density. Based on the determined course of temperatures at individual depths $(10,20,30$, and $40 \mathrm{~mm})$ under the surface of test samples of spruce wood loaded with a ceramic infrared heater with a heat flux of 15, 20, 25, and $30 \mathrm{~kW} \cdot \mathrm{m}^{-2}$, and using statistical method of least squares, we can develop a model of the course of charring in time and appropriate thickness. Reaching a temperature of $300{ }^{\circ} \mathrm{C}$ was considered critical, or marginal.

Figure 3 shows a model of the course of charred layer formation depending on heat flux loading $\left(15,20,25\right.$, and $\left.30 \mathrm{~kW} \cdot \mathrm{m}^{-2}\right)$ at individual depths (up to $10,20,30$, and $40 \mathrm{~mm}$ ) under the surface of test samples of spruce wood loaded with ceramic infrared heater in a time interval from 0 to $1920 \mathrm{~s}$.
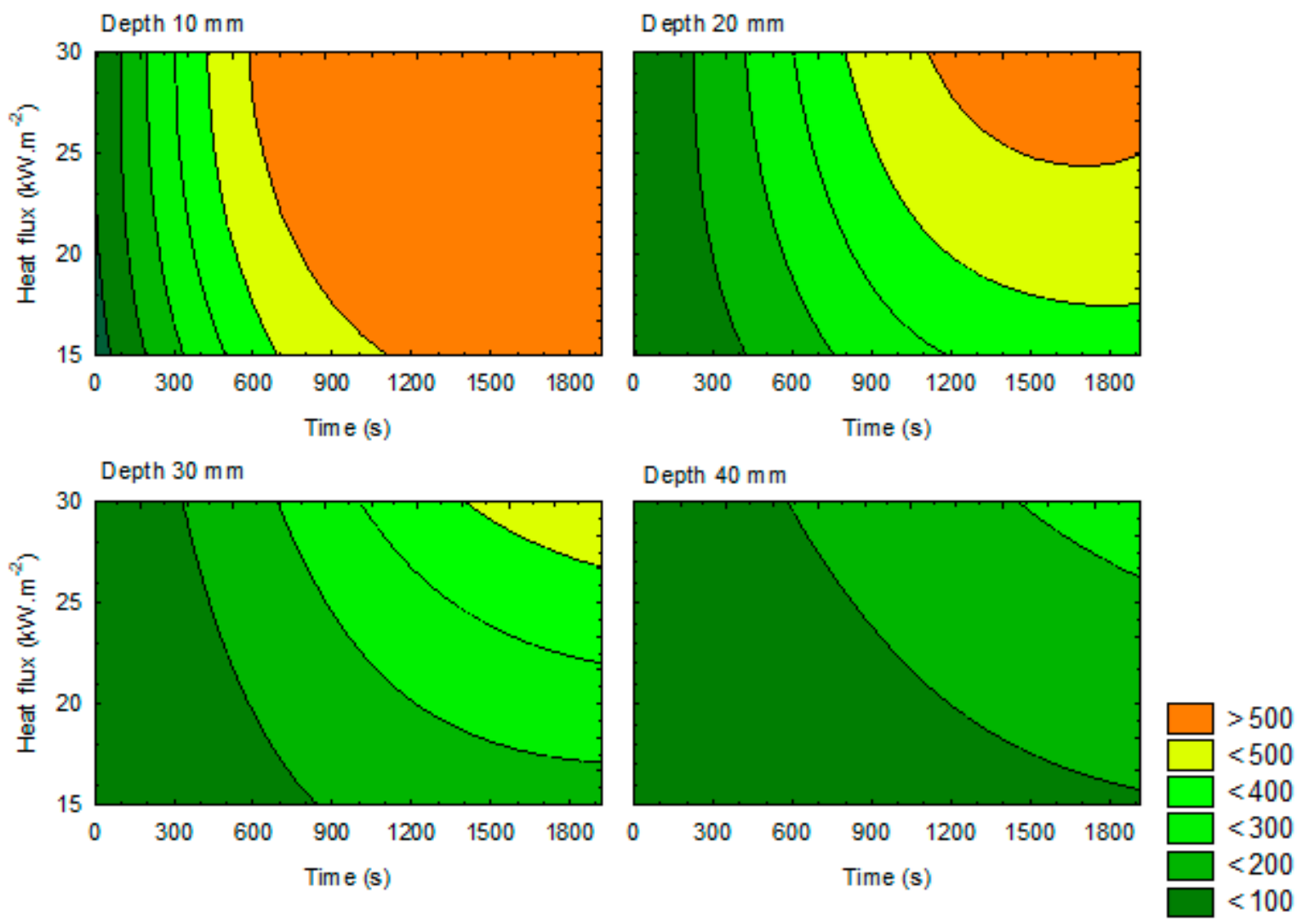

Figure 3. Model of the course of charred layer formation in time for respective depth.

The marginal temperature needed to reach a charred layer is shown in light green. It is a temperature field reaching a temperature of $300^{\circ} \mathrm{C}$ in the entire time interval (from 0 to $1920 \mathrm{~s}$ ) of thermal loading with a ceramic infrared heater. The course of charred layer 
formation up to a depth of $10 \mathrm{~mm}$ under the surface is shown upper left. The rate and extend of charred layer formation clearly indicates the dependance on the heat flux and time of loading. At a heat flux of $15 \mathrm{~kW} \cdot \mathrm{m}^{-2}$, the charred layer starts to form in a time of $200 \mathrm{~s}$ from the beginning of the loading; at a heat flux of $20 \mathrm{~kW} \cdot \mathrm{m}^{-2}$, it forms in a time of $120 \mathrm{~s}$; at a heat flux of $25 \mathrm{~kW} \cdot \mathrm{m}^{-2}$, it forms in a time of $100 \mathrm{~s}$; and at heat flux of $30 \mathrm{~kW} \cdot \mathrm{m}^{-2}$, it forms in a time of $95 \mathrm{~s}$. Based on the measurement of temperature courses in test samples on thermocouple T1, different times of reaching the critical temperature of $300{ }^{\circ} \mathrm{C}$ were recorded. The measurements show that, for charred layer formation up to a thickness of $10 \mathrm{~mm}$ under the surface, the critical heat flux at a thermal load of $15 \mathrm{~kW} \cdot \mathrm{m}^{-2}$ occurs in $505 \mathrm{~s}$, at a thermal load of $20 \mathrm{~kW} \cdot \mathrm{m}^{-2}$ occurs in $395 \mathrm{~s}$, at a thermal load of $25 \mathrm{~kW} \cdot \mathrm{m}^{-2}$ occurs in $300 \mathrm{~s}$, and at a thermal load of $30 \mathrm{~kW} \cdot \mathrm{m}^{-2}$ occurs in $315 \mathrm{~s}$, i.e., in initiation phase of the fire. The course of the charred layer formation at a depth from 10 to $20 \mathrm{~mm}$ under the surface of test samples is shown in Figure 3 (upper right). The rate and extend of the charred layer formation also indicates the dependance on the heat flux and time of loading. At a heat flux of $15 \mathrm{~kW} \cdot \mathrm{m}^{-2}$, the charred layer starts to form in a time of $760 \mathrm{~s}$ from the beginning of loading, at a heat flux of $20 \mathrm{~kW} \cdot \mathrm{m}^{-2}$ in $550 \mathrm{~s}$, at a heat flux of $25 \mathrm{~kW} \cdot \mathrm{m}^{-2}$ in $460 \mathrm{~s}$, and at a heat flux of $30 \mathrm{~kW} \cdot \mathrm{m}^{-2}$ in $415 \mathrm{~s}$. It means that, for the charred layer formation at a depth from 10 to $20 \mathrm{~mm}$ under the surface of the test sample, the critical heat flux is $30 \mathrm{~kW} \cdot \mathrm{m}^{-2}$, reached in a time of $415 \mathrm{~s}$, i.e., in the third quarter of initiation phase of the fire (up to $600 \mathrm{~s}$ from the beginning of loading). The course of the charred layer formation at a depth from 20 to $30 \mathrm{~mm}$ under the surface of test samples is shown in Figure 3 (bottom left). The rate and extent of the charred layer formation indicate the dependance on the heat flux and time of loading. At a heat flux of $15 \mathrm{~kW} \cdot \mathrm{m}^{-2}$, the charred layer was not formed within $1920 \mathrm{~s}$. At a heat flux of $15 \mathrm{~kW} \cdot \mathrm{m}^{-2}$, the critical temperature of $300{ }^{\circ} \mathrm{C}$ (recorded on thermocouple T3) was not reached during the entire time interval of thermal loading. At a heat flux of $20 \mathrm{~kW} \cdot \mathrm{m}^{-2}$, the charred layer starts to form in a time of $1180 \mathrm{~s}$, at a heat flux of $25 \mathrm{~kW} \cdot \mathrm{m}^{-2}$ in a time of $880 \mathrm{~s}$, and at a heat flux of $30 \mathrm{~kW} \cdot \mathrm{m}^{-2}$ in a time of $715 \mathrm{~s}$. The given times indicates that, for the formation of the charred layer at a depth from 20 to $30 \mathrm{~mm}$ under the surface of the test samples, the critical heat flux is $30 \mathrm{~kW} \cdot \mathrm{m}^{-2}$ in a time of $715 \mathrm{~s}$, i.e., after the initiation phase of the fire (up to $600 \mathrm{~s}$ from the beginning of loading), which is partly in conflict with our measurements, because, at a loading of $30 \mathrm{~kW} \cdot \mathrm{m}^{-2}$, the critical temperature of $300.9^{\circ} \mathrm{C}$ (recorded on thermocouple T3) was reached in a time of $980 \mathrm{~s}$ from the beginning of thermal loading.

The course of charred layer formation at a depth from 30 to $40 \mathrm{~mm}$ under the surface of test samples is shown in Figure 3 (bottom right). At a heat flux of 15,20 , and $25 \mathrm{~kW} \cdot \mathrm{m}^{-2}$, the charred layer was not formed within $1920 \mathrm{~s}$. According to our measurement of the temperature course at a loading of $15,20,25$ and $30 \mathrm{~kW} \cdot \mathrm{m}^{-2}$, the critical temperature of $300{ }^{\circ} \mathrm{C}$ (recorded on thermocouple T4) was not reached during the entire time interval of thermal loading. According to the illustration in Figure 3, the formation of charred layer at a depth of $40 \mathrm{~mm}$ under the surface occurs at a thermal loading of $30 \mathrm{~kW} \cdot \mathrm{m}^{-2}$ in a time of 1490 s, i.e., in the phase of fully developed fire.

\subsection{Changes in the Chemical Composition}

The effect of heat flux loading on chemical composition of wood is shown in Table 3.

The data show that, with increasing heat flux value, both the relative content of lignin and cellulose increases. Wang et al. [55] assessed the effect of thermal modification on the chemical properties of Masson pine (Pinus massoniana) wood. Based on their results, the relative content of lignin and cellulose increases with increasing temperature and time of thermal loading. The highest values of the abovementioned chemical components were obtained in samples loaded by a heat flux of $30 \mathrm{~kW} \cdot \mathrm{m}^{-2}$. The increase in lignin content in the thermally loaded wood indicated its higher thermal stability compared to saccharides, as well as the resulting lignin condensation [56]. The increase in the cellulose content is described as its structural changes (carbonization and crosslinking) [6]. 
Table 3. Chemical composition of the spruce wood before and after thermal loading (relative values).

\begin{tabular}{ccccccc}
\hline $\begin{array}{c}\text { Heat Flux } \\
\mathbf{( k W} \cdot \mathbf{m}^{-\mathbf{2}} \mathbf{)}\end{array}$ & $\begin{array}{c}\text { Extractives } \\
\mathbf{( \% )}\end{array}$ & $\begin{array}{c}\text { Lignin } \\
\mathbf{( \% )}\end{array}$ & $\begin{array}{c}\text { Cellulose } \\
\mathbf{( \% )}\end{array}$ & $\begin{array}{c}\text { Holocellulose } \\
\mathbf{( \% )}\end{array}$ & $\begin{array}{c}\text { Hemicelluloses } \\
\mathbf{( \% )}\end{array}$ & $\begin{array}{c}\text { C/H } \\
\text { Ratio }\end{array}$ \\
\hline Original & $1.40 \pm 0.00$ & $25.48 \pm 0.08$ & $41.23 \pm 0.03$ & $73.11 \pm 0.08$ & $31.88 \pm 0.11$ & 1.29 \\
15 & $1.09 \pm 0.00$ & $26.04 \pm 0.04$ & $43.24 \pm 0.08$ & $72.88 \pm 0.04$ & $29.64 \pm 0.12$ & 1.46 \\
20 & $1.51 \pm 0.01$ & $26.26 \pm 0.01$ & $43.14 \pm 0.00$ & $72.23 \pm 0.01$ & $29.09 \pm 0.01$ & 1.48 \\
25 & $1.19 \pm 0.00$ & $26.35 \pm 0.33$ & $45.90 \pm 0.42$ & $72.46 \pm 0.33$ & $26.56 \pm 0.09$ & 1.73 \\
30 & $1.54 \pm 0.01$ & $27.60 \pm 0.23$ & $46.92 \pm 0.17$ & $70.85 \pm 0.22$ & $23.93 \pm 0.05$ \\
\hline
\end{tabular}

${ }^{*} \mathrm{C} / \mathrm{H}$ ratio-cellulose/hemicelluloses ratio. The values are the mean \pm the $\mathrm{SD}$.

Compared to the original samples, the lowest values of hemicelluloses (decrease $24.94 \%$ ) were measured in the samples thermally loaded at higher heat flux. Wood degradation starts with deacetylation of hemicelluloses, and is followed by the depolymerization of polysaccharides, which is catalyzed by the released acetic acid [57]. The lower thermal stability of hemicelluloses than of the cellulose is visible in the $\mathrm{C} / \mathrm{H}$ ratio. It is very reliable indicator for the rate assessment of the lower stability of hemicelluloses towards cellulose [58]. Compared to the original samples, the $\mathrm{C} / \mathrm{H}$ ratio of samples loaded at $30 \mathrm{~kW} \cdot \mathrm{m}^{-2}$ is the highest (52\%); the content of extractives increased in samples loaded at 20 and $30 \mathrm{~kW} \cdot \mathrm{m}^{-2}$ and decreased in samples loaded at 15 and $25 \mathrm{~kW} \cdot \mathrm{m}^{-2}$. Several authors $[59,60]$ described a decrease and others $[56,61,62]$ an increase in extractives content in thermally loaded wood. The increase in extractives is explained by products of thermal degradation of the lignin and polysaccharides macromolecule [63].

\section{Conclusions}

Fire-technical properties, such as the mass burning rate and charring rate, and chemical composition (lignin, cellulose, hemicelluloses and extractives), of spruce wood were evaluated. Based on the determined temperatures at individual depths of 10, 20,30, and $40 \mathrm{~mm}$ under the surface of test samples loaded with a ceramic infrared heater with a heat flux of $15,20,25$, and $30 \mathrm{~kW} \cdot \mathrm{m}^{-2}$, and using statistical methods of least squares, a model of the course of charring in the given time and depth was created. This method has not been published in any original scientific paper yet.

Based on a comparison of average burning rates (at a heat flux of 15, 20, 25, and $30 \mathrm{~kW} \cdot \mathrm{m}^{-2}$ ) reached at thermal loading of samples using a ceramic infrared heater, and using our proposed test method, it can be stated that, with increasing heat flux, initiation time and time to reach the maximum burning rate of spruce wood-ranging from $0.09 \% \cdot \mathrm{s}^{-1}$ $\left(15 \mathrm{~kW} \cdot \mathrm{m}^{-2}\right)$ to $0.32 \% \cdot \mathrm{s}^{-1}\left(30 \mathrm{~kW} \cdot \mathrm{m}^{-2}\right)$-decrease.

Based on the determination of temperature course using thermocouples (type " $\mathrm{K}$ ") placed at a distance of 10,20,30, and $40 \mathrm{~mm}$ under the surface of samples loaded with a ceramic infrared heater, we could determine the burning rate in a time interval from $0 \mathrm{~s}$ to $1920 \mathrm{~s}$, which corresponds to the first three phases of the fire without the need of manual measurement. The burning rate ranges from $1.004 \mathrm{~mm} \cdot \mathrm{min}^{-1}$ at a heat flux of $15 \mathrm{~kW} \cdot \mathrm{m}^{-2}$ to $2.016 \mathrm{~mm} \cdot \mathrm{min}^{-1}$ at a heat flux of $30 \mathrm{~kW} \cdot \mathrm{m}^{-2}$.

Based on the course of temperatures, and using the statistical method of least squares, a model of the course of charring in time a respective thickness was created. The temperature of $300^{\circ} \mathrm{C}$ is considered as marginal temperature of charring, which is a benefit over the methods applied in the past.

The proposed model of the course of charring will serve for validation of computer fire models, and subsequently, the results can be used in the design and solutions for fire protection of wooden constructions.

The relative content of both lignin and cellulose increases, and hemicelluloses decreases, with higher values of heat flux loading. The lower stability of hemicelluloses towards cellulose was demonstrated via the cellulose/hemicelluloses ratio $(\mathrm{C} / \mathrm{H})$, whereas the ratio increases with higher values of heat flux loading. 
The proposed model of the course of charring will serve for validation of computer fire models, and subsequently, the results can be used in the design and solutions for fire protection of wooden constructions and as an input data for computer modelling in simulation software Ansys.

Author Contributions: M.Z. and I.Č. conceived and designed the experiments; M.Z. and I.Č. carried out the laboratory experiments; M.Z., I.C.. and D.K., L.Z. analyzed the data, interpreted the results, prepared figures, and wrote the manuscript; L.Z. carried out language corrections and translation. All authors have read and agreed to the published version of the manuscript.

Funding: This research received no external funding.

Acknowledgments: This work was supported by the Slovak Research and Development Agency under the contract No. APVV-17-0005.

Conflicts of Interest: The authors declare no conflict of interest.

\section{References}

1. Tureková, I.; Marková, I.; Ivanovičová, M.; Harangózo, J. Experimental Study of Oriented Strand Board Ignition by Radiant Heat Fluxes. Polymers 2021, 13, 709. [CrossRef]

2. Demir, A.; Aydin, I. Investigation of some surface properties and thermogravimetric analysis of veneer sheets treated with fire retardants. Maderas. Cienc. tecnol. 2019, 21, 25-34. [CrossRef]

3. Igaz, R.; Krišt'ák, L’.; Ružiak, I.; Gajtanska, M.; Kučerka, M. Thermophysical properties of OSB boards versus equilibrium moisture content. BioResources 2017, 12, 8106-8118. [CrossRef]

4. White, R.H.; Dietenberger, M.A. Wood Products: Thermal Degradation and Fire; USDA Forest Products Laboratory: Madison, WI, USA, 2016; pp. 1-7.

5. Zachar, M.; Čabalová, I.; Kačíková, D.; Jurczyková, T. Effect of Natural Aging on Oak Wood Fire Resistance. Polymers 2021, 13, 2059. [CrossRef]

6. Čabalová, I.; Zachar, M.; Kačík, F.; Tribulová, T. Impact of thermal loading on selected chemical and morphological properties of spruce ThermoWood. BioResources 2019, 14, 387-400.

7. Lowden, L.A.; Hull, T.R. Flammability behaviour of wood and a review of the methods for its reduction. Fire Sci. Rev. 2013, 2, 4. [CrossRef]

8. Makovicka-Osvaldova, L.; Markova, I.; Jochim, S.; Bares, J. Experimental Study of Straw-Based Eco-Panel Using a Small Ignition Initiator. Polymers 2021, 13, 1344. [CrossRef]

9. Vandličková, M.; Marková, I.; Makovická Osvaldová, L.; Gašpercová, S.; Svetlík, J.; Vraniak, J. Tropical Wood DustsGranulometry, Morfology and Ignition Temperature. Appl. Sci. 2020, 10, 7608. [CrossRef]

10. Taghiyari, H.R.; Militz, H.; Antov, P.; Papadopoulos, A.N. Effects of Wollastonite on Fire Properties of Particleboard Made from Wood and Chicken Feather Fibers. Coatings 2021, 11, 518. [CrossRef]

11. Martinka, J.; Hroncová, E.; Kačíková, D.; Rantuch, P.; Balog, K.; Ladomerský, J. Ignition parameters of poplar wood. Acta Fac. Xylologiae 2017, 59, 85-95.

12. Cachim, P.B.; Franssen, J.M. Assessment of Eurocode 5 charring rate calculation methods. Fire Technol. 2010, 46, 169. [CrossRef]

13. Martinka, J.; Mantanis, G.I.; Lykidis, C.; Antov, P.; Rantuch, P. The effect of partial substitution of polyphosphates by aluminium hydroxide and borates on the technological and fire properties of medium density fibreboard. Wood Mat. Sci. Eng. $2021,1-7$. [CrossRef]

14. Qin, R.; Zhou, A.; Chow, C.L.; Lau, D. Structural performance and charring of loaded wood under fire. Eng. Struct. 2021, 228, 111491. [CrossRef]

15. Richter, F.; Atreya, A.; Kotsovinos, P.; Rein, G. The effect of chemical composition on the charring of wood across scales. Proc. Combust. Inst. 2019, 37, 4053-4061. [CrossRef]

16. STN. EN 1995-1-2-Eurocode 5: Design of Timber Structures-Part 1-2: General; Structural Fire Design. 2008. Available online: https:/ / silo.tips/download/pren-eurocode-5-design-of-timber-structures-part-1-2-general-rules-structural-fi (accessed on 9 August 2021).

17. Chu, D.; Mu, J.; Avramidis, S.; Rahimi, S.; Liu, S.; Lai, Z. Functionalized Surface Layer on Poplar Wood Fabricated by Fire Retardant and Thermal Densification. Part 1: Compression Recovery and Flammability. Forests 2019, 10, 955. [CrossRef]

18. NFPA 921; Guide for Fire and Explosion Investigations; National Fire Protection Association: Quincy, MA, USA, 2021.

19. Zhou, A.; Qin, R.; Chow, C.L.; Lau, D. Bond integrity of aramid, basalt and carbon fiber reinforced polymer bonded wood composites at elevated temperature. Compos. Struct. 2020, 245, 112342. [CrossRef]

20. Fonseca, E.M.M.; Barreira, L.M.S. Charring rate determination of wood pine profiles submitted to high temperatures. Safety and Security Engineering III. WIT Trans. Built Environ. 2009, 108, 449-457.

21. White, R.H.; Nordheim, E.V. Charring rate of wood for ASTM E 119 exposure. Fire Technol. 1992, 28, 5-30. [CrossRef] 
22. Findorák, R.; Fröhlichová, M.; Legemza, J.; Findorákova, L. Thermal degradation and kinetic study of sawdusts and walnut shells via thermal analysis. J. Therm. Anal. Calorim. 2016, 125, 689-694. [CrossRef]

23. Chen, T.; Wu, W.; Wu, J.; Cai, J.; Wu, J. Determination of the pseudocomponents and kinetic analysis of selected combustible solid wastes pyrolysis based on Weibull model. J. Therm. Anal. Calorim. 2016, 126, 1899-1909. [CrossRef]

24. Babrauskas, V. Charring rate of wood as a tool for fire investigations. Fire Saf. J. 2005, 40, 528-554. [CrossRef]

25. ASTM E119-20; Standard Test Methods for Fire Tests of Building Construction and Materials; ASTM International: West Conshohocken, PA, USA, 2020.

26. ISO 834-2; Fire-Resistance Tests-Elements of Building Construction-Part 2: Requirements and Recommendations for Measuring Furnace Exposure on Test Samples; International Organization for Standardization: Geneva, Switzerland, 2019.

27. Csanády, E.; Magoss, E.; Tolvaj, L. Quality of Machined Wood Surfaces, 1st ed.; Springer International Publishing: New York, NY, USA, 2015; 257p.

28. Kučerová, V.; Lagaňa, R.; Výbohová, E.; Hýrošová, T. The effect of chemical changes during heat treatment on the color and mechanical properties of fir wood. BioResources 2016, 11, 9079-9094. [CrossRef]

29. Sikora, A.; Kačík, F.; Gaff, M.; Vohndrová, V.; Bubeníková, T.; Kubovský, I. Impact of thermal modification on color and chemical changes of spruce and oak wood. J. Wood Sci. 2018, 64, 406-416. [CrossRef]

30. Ganne-Chédeville, C.; Jääskeläinen, A.-S.; Froidevaux, J.; Hughes, M.; Navi, P. Natural and artificial ageing of spruce wood as observed by FTIR-ATR and UVRR spectroscopy. Holzforschung 2012, 66, 163-170. [CrossRef]

31. Rantuch, P.; Chrebet, T. Thermal decomposition of cellulose insulation. Cel. Chem. Technol. 2014, 48, 46-467.

32. Gaan, S.; Rupper, P.; Salimova, V.; Heuberger, M.; Rabe, S.; Vogel, F. Thermal decomposition and burning behavior of cellulose treated with ethyl ester phosphoramidates: Effect of alkyl substituent on nitrogen atom. Polym. Degrad. Stabil. 2009, 94, 1125-1134. [CrossRef]

33. Poletto, M. Effect of extractive content on the thermal stability of two wood species from Brazil. Cienc. Tecnol. 2016, 18, 435-442. [CrossRef]

34. ISO 10694; Soil Quality. Determination of Organic and Total Carbon after Dry Combustion (Elementary Analysis); International Organization for Standardization: Geneva, Switzerland, 1995.

35. ISO 13878; Soil quality. Determination of Total Nitrogen Content by Dry Combustion (Elemental Analysis); International Organization for Standardization: Geneva, Switzerland, 1998.

36. ISO 15178; Soil quality. Determination of Total Sulfur by Dry Combustion; International Organization for Standardization: Geneva, Switzerland, 2000.

37. ISO 11885; Water quality. Determination of Selected Elements by Inductively Coupled Plasma Optical Emission Spectrometry (ICP-OES); International Organization for Standardization: Geneva, Switzerland, 2007.

38. ISO 11925-2; Reaction to Fire Tests-Ignitability of Products Subjected to Direct Impingement of Flame-Part 2: Single-Flame Source Test; International Organization for Standardization: Geneva, Switzerland, 2020.

39. ASTM D1107-21; Standard Test Method for Ethanol-Toluene Solubility of Wood; ASTM International: West Conshohocken, PA, USA, 2021.

40. Sluiter, A.; Hames, B.; Ruiz, R.; Scarlata, C.; Sluiter, J.; Templeton, D.; Crocker, D. Determination of Structural Carbohydrates and Lignin in Biomass (NREL/TP-510-42618); National Renewable Energy Laboratory: Golden, CO, USA, 2012.

41. Seifert, V.K. About a new method for rapid determination of pure cellulose (in German). Das. Pap. 1956, 10, 301-306.

42. Wise, L.E.; Murphy, M.; D'addieco, A.A. Chlorite holocellulose, its fractionation and bearing on summative wood analysis and on studies on the hemicelluloses. Pap. Trade J. 1946, 122, 35-44.

43. Zachar, M.; Mitterová, I.; Xu, Q.; Majlingová, A.; Cong, J.; Galla, Š. Determination of fire and burning properties of spruce wood. Drv. Ind. 2012, 63, 217-223. [CrossRef]

44. STN ISO 871; Plastics. Determination of Ignition Temperature Using a Hot-Air Oven; International Organization for Standardization: Geneva, Switzerland, 2010.

45. Delichatsios, M.; Paroz, B.; Bhargava, A. Flammability properties for charring materials. Fire Saf. J. 2003, 38, 219-228. [CrossRef]

46. Hagen, M.; Hereid, J.; Delichatsios, M.A.; Zhang, J.; Bakirtzis, D. Flammability assessment of fire-retarded Nordic Spruce wood using thermogravimetric analyses and cone calorimetry. Fire Saf. J. 2009, 44, 1053-1066. [CrossRef]

47. Makovická-Osvaldová, L.; Kadlicová, P.; Rychlý, J. Fire Characteristics of Selected Tropical Woods without and with Fire Retardant. Coatings 2020, 10, 527. [CrossRef]

48. Gaff, M.; Kačík, F.; Gašparík, M.; Todaro, L.; Jones, D.; Corleto, R.; Makovická-Osvaldová, L.; Čekovská, H. The effect of synthetic and natural fire-retardants on burning and chemical characteristics of thermally modified teak (Tectona grandis L. f.) wood. Constr. Build. Mater. 2019, 200, 551-558. [CrossRef]

49. Kačíková, D.; Makovická, L. Wood burning rate of various tree parts from selected softwoods. Acta Fac. Xylologiae 2009, 51, 27-32.

50. Makovická-Osvaldová, L.M.; Gašpercová, S.; Mitrenga, P.; Osvald, A. The influence of density of test specimens on the quality assessment of retarding effects of fire retardants. Wood Res. 2016, 61, 35-42.

51. Lipinskas, D.; Mačiulaitis, R. Further opportunities for development of the method for fire origin prognosis. J. Civil. Eng. Manag. 2005, 11, 299-307. [CrossRef]

52. Martinka, J.; Rantuch, P.; Liner, M. Calculation of charring rate and char depth of spruce and pine wood from mass loss. J. Therm. Anal. Calorim. 2018, 132, 1105-1113. [CrossRef] 
53. Zhang, L.; Li, T.; Quyn, D.; Dong, L.; Qiu, P.; Li, C.Z. Formation of nascent char structure during the fast pyrolysis of mallee wood and low-rank coals. Fuel 2015, 150, 486-492.

54. Lizhong, Y.; Yupeng, Z.; Yafei, W.; Zaifu, G. Predicting charring rate of woods exposed to time increasing and constant heat fluxes. J. Anal. Appl. Pyrolysis. 2008, 81, 1-6. [CrossRef]

55. Wang, X.; Chen, X.; Xie, X.; Wu, Y.; Zhao, L.; Li, Y.; Wang, S. Effects of thermal modification on the physical, chemical and micromechanical properties of Masson pine wood (Pinus massoniana Lamb.). Holzforschung 2018, 72, 1063-1070. [CrossRef]

56. Kačík, F.; Luptáková, J.; Šmíra, P.; Nasswettrová, A.; Kačíková, D.; Vacek, V. Chemical alterations of pine wood lignin during heat sterilization. BioResources 2016, 11, 3442-3452. [CrossRef]

57. Nuopponen, M.; Vuorinen, T.; Jämsä, S.; Viitaniemi, P. Thermal modification in softwood studied by FT-IR and UV resonance raman spectroscopies. J. Wood Chem. Technol. 2005, 24, 13-26. [CrossRef]

58. Kačík, F.; Šmíra, P.; Kačíková, D.; Reinprecht, L.; Nasswettrova, A. Chemical changes in fir wood from old buildings due to ageing. Cell. Chem. Technol. 2014, 48, 79-88.

59. Hrčka, R.; Kučerová, V.; Hýrošová, T.; Honig, V. Cell Wall Saturation Limit and Selected Properties of Thermally Modified Oak Wood and Cellulose. Forests 2020, 11, 640. [CrossRef]

60. Kučerová, V.; Kačíková, D.; Kačík, F. Alterations of extractives and cellulose macromolecular characteristics after thermal degradation of spruce wood (in Slovak). Acta Fac. Xylologiae 2011, 53, 77-83.

61. Zachar, M.; Majlingová, A.; Mitterová, I.; Čabalová, I. Influence of an age and damage of the oak wood in its fire risk. Wood Res. 2017, 62, 495-504.

62. Wikberg, H.; Maunu, S.L. Characterisation of thermally modified hard- and softwoods by ${ }^{13}$ C CPMAS NMR. Carbohyd. Polym. 2004, 58, 461-466. [CrossRef]

63. Esteves, B.; Graca, J.; Pereira, H. Extractive composition and summative chemical analysis of thermally treated eucalypt wood. Holzforschung 2008, 62, 344-351. [CrossRef] 